\title{
Research article \\ Assessment of the routinely used surface disinfectants in hospital care settings by using different quantitative methods
}

\author{
Praveen Kumar Prakasam ${ }^{1}$, Namrata K. Bhosale ${ }^{2}$, K. S. Seetha ${ }^{3}$
}

${ }^{1}$ MBBS Student, ${ }^{2}$ Associate Professor, ${ }^{3}$ Former Professor and Head, Department of Microbiology, Mahatma Gandhi Medical College \& Research Institute, Sri Balaji Vidyapeeth (Deemed-to-be-University), Pillaiyarkuppam, Puducherry, 607 402, India

(Received: July 2020

Revised: April 2021

Accepted: April 2021)

Corresponding author: Namrata K. Bhosale. Email: namukb1234@gmail.com

\begin{abstract}
Introduction and Aim: Disinfectants play a vital role in the prevention of nosocomial infections. A variety of disinfectants with different mechanism of action are available in the market. Most of the hospitals and health care centres select the disinfectants trusting the claims made by the manufacturers which may not be authentic.

Materials and Methods: Plenty of standardised in-house disinfection testing methods are available but because of their complex procedure most of them are not feasible. Thus, in our study we employed a simple "quantitative suspension method" for testing the efficiency of the disinfectants. Commercially available disinfectants- Srivlon, Emplura, Hospal-OT, and NICE were tested against three nosocomial pathogens - Pseudomonas aeruginosa, MRSA, and Candida albicans.
\end{abstract}

Results: In this study, the commercial disinfectants were acted effectively against all the three organisms. HospalOT had the maximum bactericidal activity followed by Srivlon disinfectant.

Conclusion: Our study concluded that all the four commercial disinfectants were acted against the pathogens viz., Pseudomonas aeruginosa, MRSA and Candida albicans. Among four disinfectants, Srivlon needs a regular monitoring because of poor performance. Therefore, the proper usage of concentration and contact period of disinfectant will provide an efficient action against the pathogenic microbial population.

Keywords: Disinfectant; nosocomial infections; hospital infection control; Candida albicans, Pseudomonas aeruginosa; MRSA.

\section{INTRODUCTION}

$\mathrm{S}$ urface disinfectants is highly an integral part of the infection control measures which helps in preventing the spread of hospital acquired infections. It is mostly used in the surfaces of the tables, door handles, bed railings, medicine racks, trolleys, instruments, walls and floors in OPD, wards and operation theatres. Mechanism of disinfectants are mainly used to eliminates the pathogenic organisms on inanimate objects including bacterial spores $(1,2)$. Surface disinfectants are commonly used in hospitals which includes sodium hypochlorite, iodophors, quaternary ammonium and phenolic compounds. Different varieties of disinfectants are used in the hospital as well as environmental based on their effectiveness on the vegetative bacteria, fungus and deadly viruses (1). Numerous factors viz., $\mathrm{pH}$, microbial load, exposure time and concentration of the disinfectants which affects its efficacy (2). Nowadays, many hospitals in our nation still they don't have any prescribed protocol for testing the quality of the disinfectants (1). There are various standard methods have been developed to check the proficiency of disinfectant which includes viz., Rideal-Walker phenol coefficient (R.W.C) test (3), Chick-Martin and Garrod's test, capacity use dilution test by Kelsey and Sykes, microbial time kill assays and Kesley and Maurer's in-use tests (4-6). These tests have been classified as quantitative, semi-quantitative and qualitative, or alternative tests. Most of the tests used for testing disinfectants are rarely followed in hospitals because of their complex procedure (6). Carrier and Suspension tests are still used for testing the disinfectants using immersed in liquid culture to check the viability of the mixture $(7,8)$. Health care workers have lack of awareness by choosing a disinfectant because of the instructions provided by some of the local manufacturers which was not highly reliable on their products (8). The main aim of this study is to perform the 'quantitative suspension method' for testing the efficacy of disinfectants used in our health care centre.

\section{MATERIALS AND METHODS}

This was an analytic study conducted in the microbiology department of a tertiary care hospital. The study commenced only after obtaining the approval from the Institutional Human Ethics Committee (IHEC). The study was carried out for the period of two months, August to September 2016. The following disinfectants are tested with microorganisms:

1. Hospital-OT (1,6 Dihydroxy,2,5, Dioxyhexane, glutaraldehyde, benzalkonium chloride solution, alkyl urea derivative). Working solution made to $1 \%$. 
2. Srilvon (chlorhexidine gluconate, cetrimide, isopropyl alcohol)

3. NICE (sodium hypochlorite solution; $5 \% \mathrm{w} / \mathrm{v}$ ) Diluted in a ratio of 1:100

The list of tested organisms against the above disinfectants are:

- Candida albicans

- Pseudomonas aeruginosa

- Methicillin resistant Staphylococcus aureus (MRSA)

Hospital strains of above-mentioned organisms were obtained from our diagnostic laboratory. In the present study, Dey-Engley neutralising broth (Hi-Media, India) were utilized for Quantitative suspension method $(9,10)$. Briefly, $0.5 \mathrm{McF}$ arland broth with the suspension of the test organism was prepared by using normal saline. About $100 \mu$ l of this suspension was added to the $10 \mathrm{ml}$ of disinfectant. All disinfectants were used by their manufacturer's instructions. After observing the action of disinfectants for defined durations (5, 10, 20 and $30 \mathrm{mins}), 1 \mathrm{ml}$ of mixture was transferred to $9 \mathrm{ml}$ of neutralising solution $(0.1 \%$ Tween 80 and $1 \%$ sodium thiosulphate). Approximately after $10 \mathrm{mins}$, transfer the $1 \mathrm{ml}$ of suspension from the neutralizing tube to the nutrient broth which was serially diluted from tube 1 to tube 5 $\left(1: 10\right.$ to $\left.1: 10^{5}\right)$ and $100 \mu 1$ from each dilution will be plated on nutrient agar using the spread-plate technique with the help of a sterile glass spatula. Nutrient agar plates were incubated at $37^{\circ} \mathrm{C}$ for $24-48$ hrs. For quality check, the test was carried out in triplicates for each disinfectant. Controls for all the three organisms were performed by transferring $100 \mu 1$ of the $0.5 \mathrm{McFarland}$ broths of the test organisms to the diluents without disinfectant. Colonies grown in the agar plates the colonies were expressed as colony forming units (CFU) per millilitre.
The following formula was used to calculate the Efficacy of disinfectant:

$$
\text { RF }=\log N c-\log N d
$$

Where RF denotes Logarithmic Reduction Factor; Nc denotes Total number of colonies from control plates; Nd denotes Total number of colonies from test plates. A Log 10 reduction of 5 or more indicates satisfactory microbicidal activity i.e. $99.99 \%$ of the germs to be killed.

\section{Statistical Analysis}

The data was analysed using the EpiData software (Version 10.0) utilising the Analysis of variance (oneway ANOVA) test to evaluate the type of disinfectants and organisms show an impact on reduction of colony counts. $P$ value $(p<0.005)$ were statistically significant.

\section{RESULTS}

Results were expressed in terms of $\log _{10}$ reductions against different contact times and tabulated for comparison. All four of our disinfectants which was used in this study were showed a good microbiocidal activity. Among these disinfectants, Hospal-OT were showed more effective on the three pathogens when compared to the other three disinfectants. Microorganisms like Pseudomonas aeruginosa (Table 1), Methicillin Resistant Staphylococcus aureus (Table 2) and Candida albicans (Table 3) were tested with four different disinfectants in hospital settings. The lowest microbiocidal activity was observed in Sriylon. A statistical significance was observed in Hospal - OT 1\%. The microbicidal effect of all the disinfectants was increased by increasing the contact time from 5 to 10 minutes but there was no improvement with subsequent increase in contact time (i.e., at 20 and 30 mins).

Table 1: Testing of Pseudomonas aeruginosa with four different disinfectants utilized in hospital care settings

\begin{tabular}{|c|c|c|c|c|}
\hline \multirow{2}{*}{$\begin{array}{c}\text { Name of } \\
\text { disinfectant }\end{array}$} & \multicolumn{4}{|c|}{ Log reductions against various contact time } \\
\cline { 2 - 5 } & $\mathbf{5}$ min & $\mathbf{1 0}$ min & $\mathbf{2 0}$ min & 30 min \\
\hline Hospal-OT 1\% & 6.52 & 8.45 & 8.45 & 8.45 \\
\hline Srivlon & 5.25 & 6.10 & 6.10 & 6.10 \\
\hline Emplura & 7.65 & 8.25 & 8.91 & 8.91 \\
\hline NICE & 7.29 & 8.38 & 8.38 & 8.38 \\
\hline
\end{tabular}

Table 2: Testing of Methicillin resistant Staphylococcus aureus (MRSA) with four different disinfectants Utilized in hospital care settings

\begin{tabular}{|c|c|c|c|c|}
\hline \multirow{2}{*}{$\begin{array}{c}\text { Name of } \\
\text { disinfectant }\end{array}$} & \multicolumn{4}{|c|}{ Log reductions against various contact time } \\
\cline { 2 - 5 } & $\mathbf{5}$ min & $\mathbf{1 0}$ min & $\mathbf{2 0}$ min & 30 min \\
\hline Hospal-OT 1\% & 7.65 & 8.55 & 8.55 & 8.55 \\
\hline Srivlon & 5.38 & 6.28 & 6.28 & 6.28 \\
\hline Emplura & 7.50 & 8.53 & 8.53 & 8.53 \\
\hline NICE & 7.42 & 8.33 & 8.33 & 8.33 \\
\hline
\end{tabular}

Table 3: Testing of Candida albicans with four different disinfectants utilized in hospital care settings

\begin{tabular}{|c|c|c|c|c|}
\hline \multirow{2}{*}{$\begin{array}{c}\text { Name of } \\
\text { disinfectant }\end{array}$} & \multicolumn{4}{|c|}{ Log reductions against various contact time } \\
\cline { 2 - 5 } & $\mathbf{5} \mathbf{~ m i n}$ & $\mathbf{1 0} \mathbf{~ m i n}$ & $\mathbf{2 0} \mathbf{~ m i n}$ & $\mathbf{3 0} \mathbf{~ m i n}$ \\
\hline Hospal-OT 1\% & 6.98 & 8.52 & 8.52 & 8.52 \\
\hline
\end{tabular}




\begin{tabular}{|c|c|c|c|c|}
\hline Srivlon & 5.98 & 6.78 & 6.78 & 6.78 \\
\hline Emplura & 7.88 & 8.74 & 8.74 & 8.74 \\
\hline NICE & 7.25 & 8.66 & 8.66 & 8.66 \\
\hline
\end{tabular}

\section{DISCUSSION}

Disinfectants play a vital role in preventing the hospital infections. Thus, it is mandatory to monitor the quality of the disinfectant, which was regularly used in the hospital sectors $(1,11)$. In the present study, the quantitative suspension test was performed to evaluate the microbicidal activity of the commercially available disinfectants and their use of concentration (10). Disinfectants are probably involved in the reduction of microbial load in the hospital wards as well as operation theatres. Kumar et al., evaluated the disinfectant that the minimum $5 \log$ series of reduction is used for the contact time of the solutions (11). It was demonstrated that the Bacilloid, a disinfectant had more efficiency to kill the microorganisms. But in this study, three different types of commercially available disinfectants were used viz, Hospal-OT, Srilvon and NICE. In this study, the three microbial strains were used which was routinely isolated from the clinical samples in our hospital. In the current study, all three disinfectants were used and showed that the satisfactory performance on microbicidal activity against the three hospital strains at different contact times. Among three disinfectants, Hospal-OT had highest log reduction of microbial count against MRSA. Our findings are excited with other studies usage of disinfectants viz., Hospal - OT (11). Significantly there was increase in the microbicidal activity of the contact time was increased upto 10 minutes, but there was no difference in subsequently increasing in contact times. The two disinfectants Emplura and NICE were showed a good microbicidal effect on pathogens at different contact times were routinely used. Most effective disinfectant was used in the laboratory is sodium hypochlorite which acts primarily against the viruses, bacteria and fungus $(12,13)$. Previously, many researchers have documented that Srivlon was satisfactory, but it shows less clearance on the pathogens when compared to the other two disinfectants. Many efficient researchers have recorded about the efficacy of disinfectants in various sections like dental water lines and hospital centres (14-17). This could be possibly due to improper dilution or incorrect concentration details mentioned by the manufacturer.

\section{CONCLUSION}

Our study concluded that all the four commercial disinfectants used in this study had broad activity against the pathogens viz., Pseudomonas aeruginosa, MRSA and Candida albicans. Among four disinfectants, Srivlon stresses a regular monitoring due to the poor performance of the disinfectants used in a hospital. Proper usage of concentration and contact period of disinfectant will provide an efficient action against the microbes. Formulation of standardised policy for selection and usage of disinfectants will lead to avoidance of substandard quality of disinfectants.

\section{ACKNOWLEGEMENTS}

We are grateful to Hon'ble Chancellor, Vicechancellor, Sri Balaji Vidyapeeth (Deemed-to-beUniversity), Dean (Academic) and Head of the Department, Microbiology, Mahatma Gandhi Medical College \& Research Institute, Puducherry for providing facilities for this Indian Council of Medical Research (ICMR) Short Term Student (STS) research project conducted in the year 2016.

\section{CONFLICT OF INTEREST}

None to declare

\section{REFERENCES}

1. Guideline for Disinfection and Sterilization in Healthcare Facilities, 2008 - Disinfection_Nov_2008.pdf [Internet]. [cited 2016 Oct 1]. Available from: https://www.cdc.gov/hicpac/pdf/guidelines/Disinfection_No v_2008.pdf

2. Grota, P., Ackiss, E. A., eds. APIC Text of Infection Control and Epidemiology, 4th ed. Washington, DC: Association for Professionals in Infection Control and Epidemiology; 2014.

3. Rideal, S., Walker, J. T. A. Approved Technique of the Rideal-Walker Test. Am J Public Health N Y N. 1913; 3(6): 575-581.

4. Garrod, L.P. A Study of the Chick-Martin Test for Disinfectants. J Hyg (Lond). 1934; 34(3): 322-332.

5. Christensen, E. A., Jepsen, O. B., Kristensen, H., Steen, G. In-use tests of disinfectants. Acta Pathol Microbiol Immunol Scand. 1982; 90(2): 95-100.

6. Kawamura-Sato, K., Wachino, J., Kondo, T., Ito, H., Arakawa, Y. Reduction of disinfectant bactericidal activities in clinically isolated Acinetobacter species in the presence of organic material. J Antimicrob Chemother. 2008; 61(3): 568576.

7. Reybrouck, G. Milestones in the testing of surface disinfectants: from Robert Koch to CEN TC 216. GMS Krankenhaushygiene Interdiszip [Internet]. 2007 Sep 13 [cited 2016 Oct 1]; 2(1). Available from: http://www.ncbi.nlm.nih.gov/pmc/articles/PMC2831497/

8. Kelsey, J. C. S. G. A new test for the assessment of disinfectants with particular reference to their use in hospitals. Pharm J. 1969; (202): 607-609.

9. Klingeren, V. B. Disinfectant testing on surfaces. J Hosp Infect. 1995; 30: 397-408.

10. Hernández, A., Martró, E., Matas, L., Ausina, V. In-vitro evaluation of Perasafe $\AA$ compared with $2 \%$ alkaline glutaraldehyde against Mycobacterium spp. J Hosp Infect. 2003; 54(1): 52-56.

11. Kumar, I., Kulkarni, M., Babu, B. H. Selection and microbial control of disinfectants and validation of disinfectant microbial efficacy in the pharma \& biopharmaceutical industry: a case study. Int J Bioassays. 2014; 3(5): 20792082.

12. Fukuzaki, S. Mechanisms of actions of sodium hypochlorite in cleaning and disinfection processes. Biocontrol Sci. 2006; 11(4): 147-157.

13. Olasehinde, G. I., Akinyanju, J. A., Ajayi, A. A. Comparative antimicrobial activity of commercial disinfectants with naphtholics. Res J Microbiol. 2008; 3(4): 262-268. 
14. Patel, M., Desai, J., Owen, P.C. The efficacy of disinfectants in the decontamination of dental unit water lines: an in vitro laboratory study. BDJ Open. 2016;2:16003.

15. Boyce, J. M. Modern technologies for improving cleaning and disinfection of environmental surfaces in hospitals. Antimicrob Resist Infect Control. 2016; 5: 10.

16. Song, X., Vossebein, L, Zille. A. Efficacy of disinfectantimpregnated wipes used for surface disinfection in hospitals: a review. Antimicrob Resist Infect Control. 2019; 8: 139.

17. Anderson, D. J., Moehring, R.W., Weber, D. J., Lewis, S. S., Chen, L. F., Schwab, J. C, et al., CDC Prevention Epicenters Program. Effectiveness of targeted enhanced terminal room disinfection on hospital-wide acquisition and infection with multidrug-resistant organisms and Clostridium dificile: a secondary analysis of a multicentre cluster. 